\title{
Variability is the nature of the endophyte-grass interaction
}

\author{
S.H. FAETH ${ }^{1}$ and K. SAIKKONEN ${ }^{2}$ \\ ${ }^{1}$ Arizona State University, School of Life Sciences, PO Box 874501, Tempe AZ 85287-4501 \\ ${ }^{2}$ MTT Agrifood Research Finland, Plant Production Research, Karilantie 2 A, FI-50600 Mikkeli, Finland \\ s.faeth@asu.edu
}

\begin{abstract}
Studies of systemic endophyte in grasses have skyrocketed in the past two decades. However, the vast majority of these studies still occur in agroecosystems. We show that ecological and evolutionary concepts derived from these systems may be misleading because they fail to incorporate the enormous variability found in endophyte-host grass interactions in wild grass populations. This variability stems from 1) genetic differences in host plants and endophytes, 2) environmental factors such as light and soil nutrients and moisture, and 3) the tangled web of interacting species in natural communities, such as conspecific and interspecific plants, multiple generalist and specialist herbivore species, and the third trophic level, predators and parasites. Studies of natural populations and communities continue to lag far behind those involving agronomic grass systems. However, we argue that additional studies of infected wild grass populations and communities are essential to advance ecological and evolutionary concepts of endophytegrass interactions.
\end{abstract}

Keywords: endophytes, herbivore resistance, grasses, natural populations and communities, natural enemies, Neotyphodium, pathogens, plant defenses, variability

\section{Introduction}

In the past few decades, agronomists, ecologists and evolutionary biologists have learned a great deal about the nature of the interaction between Neotyphodium endophytes and their grass hosts. Great strides have been made in understanding the relationship between Neotyphodium endophytes and their associated alkaloids relative to herbivore and pathogen resistance and allelopathic effects. Furthermore, detailed understanding of the role of endophytes in alleviating drought and nutrient stress and enhancing competitive abilities has been made. Not only have the physiological, morphological, growth, reproductive, and

Figure 1 Cumulative number of endophyte studies by year involving either introduced agronomic grasses or wild (native, non-agronomic) grasses.

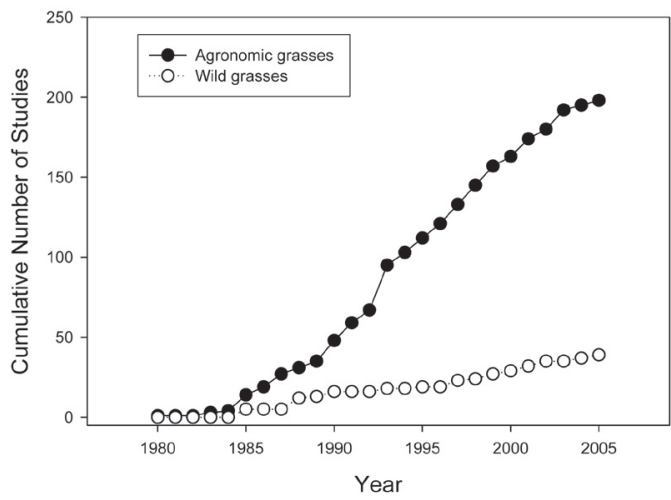

anti-herbivore effects of endophyte infection been thoroughly examined empirically, but more recently studies have been extended to the consequences of endophyte infection at the population, community, and ecosystem level.

However, nearly all the studies and experiments involving physiological, population, community and ecosystem level effects of endophytes have involved three introduced, agronomic grasses and their Neotyphodium endophytes - tall fescue (Lolium arundinaceum), notably Kentucky 31 variety, perennial ryegrass (Lolium perenne) and more recently annual Italian ryegrass (Lolium multiflorum). Studies of natural endophyte-host interactions, while increasing slightly in the past two decades, still lag far behind those involving introduced grasses (Fig. 1). Agronomic grasses, especially tall fescue, have been touted as model systems in which to examine and test endophytehost interactions. At each biological organisational level, we can expect increasing variability in the outcome of endophyte interactions with their hosts, simply due to escalating complexity at higher organisational levels. The main question we ask is: do these agronomic grass-endophyte systems accurately capture the variability found in wild or natural grass and endophyte systems? This is, after all, the main goal of a model system (e.g. Robert 2004). If a model system in any area of science, such as biomedicine, fails to include the inherent variability found in the systems in which it is intended to model, then it has limited value.

We approach this question in several ways. First, we report results of a recent meta-analysis of the primary literature of grassendophyte studies. We discuss reasons why agronomic grass systems appear to make poor model systems for understanding the ecology and evolution of grass-endophyte interactions and their interactions. Second, we report results of recent studies of wild or natural grass populations at the physiological, population, and community levels that demonstrate remarkable variability in their outcomes. These variable outcomes are not adequately encompassed by agronomic grass model systems. Note that by 'wild or natural' we refer to natural grass-endophyte systems in their endemic habitats. Agronomists often refer to wild-type endophytes as meaning the endophytes that were naturally found in the introduced grass cultivar and have not been altered or engineered. However, these wild-type endophytes are in grass cultivars that have been highly selected for agronomic turf or pasture grasses, and are typically grown in areas of introduction. For our purposes, wild grasses are just that, grasses with their natural-occurring endophytes growing in their endemic habitats, without selective breeding or other manipulations. Finally, given the dearth of studies of natural or wild grasses and their Neotyphodium endophytes, we call for increased attention to these natural systems if we are to understand the nature of the endophyte-grass interaction.

Do Agronomic Grasses make Good Model Systems for the Ecology of Endophyte-Grass Interactions?

Model systems have often been used in the biological and biomedical sciences as convenient and low cost short-cuts to focus research on a particular problem or concept (Saikkonen et 
Figure 2 Temporal changes in the magnitude of endophyte-mediated plant a) competition, b) performance and c) resistance to herbivores from the initiation of endophyte studies to 2005 . Effect size is a Fisher's z-transformed correlation coefficient $(\mathrm{Zr})$. Error bars represent $95 \%$ confidence intervals. Positive effects (to the right of the zero effect size) indicate benefits or positive effects of the endophyte on the host grass. Significant effect sizes occur when the $95 \% \mathrm{Cl}$ do not overlap the zero effect size (vertical line).

a)

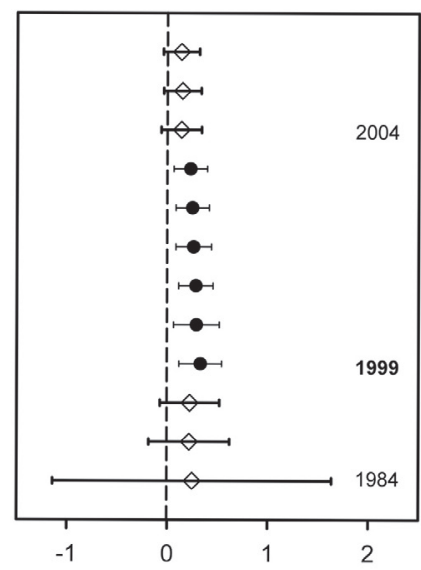

b)

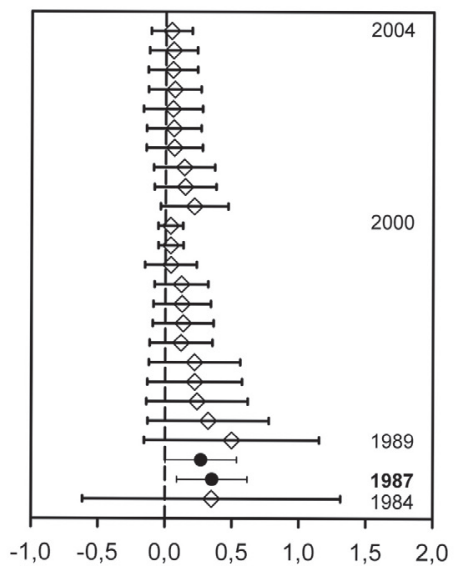

c)

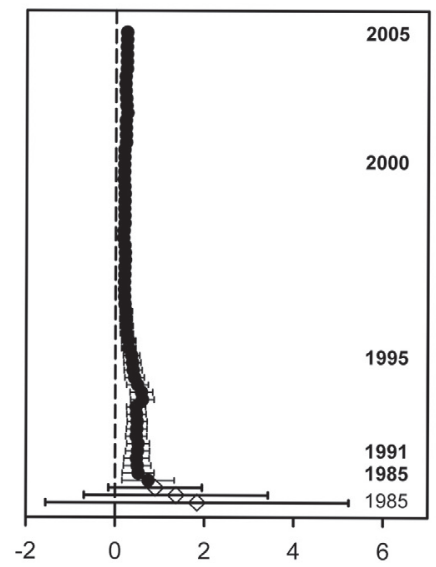

\section{Effect size $(\mathrm{Zr}+95 \% \mathrm{Cl})$}

al. 2006). For example, mouse and Drosophila model systems have been instrumental in medicine and genetics, Xenopus and $C$. elegans in evolutionary developmental biology, and Arabadopsis in plant sciences (e.g. Robert 2004). Ecology has had fewer model systems, probably because the inherent variation found at in the higher organisational levels of population, community and ecosystem ecology prohibits a single system that adequately represents this complexity.

Nonetheless, introduced agronomic grasses and their endophytes have become de facto model systems for developing concepts of Neotyphodium-grass interactions and their implications for population, community and ecosystem patterns and processes. The overall outcome from these studies is that Neotyphodium is highly mutualistic with its grass host, conferring advantages in terms of resistance to herbivores, increased plant performance, and generally increased competitive abilities. This concept persists today and is often stated as such in introductions to a wide variety of scientific investigations of endophytes, ranging from phylogenetic (e.g. Clay \& Schardl 2002) to ecosystem level studies (e.g. Rudgers et al. 2004; Lemons et al. 2005). More than any other agronomic system, Kentucky 31 tall fescue has been used as a model system for concepts of grass-endophyte interactions spanning the range of physiological, plant-herbivore, community (including biodiversity, trophic relationships, invasibility) and ecosystem studies (e.g., Clay \& Holah 1999; Clay et al. 2005; Rudgers et al. 2004; Lemons et al. 2005; Finkes et al. 2006). From this model system, coupled with agronomic perennial ryegrass (e.g. Kraus et al. 2006) and more recently, annual Italian ryegrass (e.g. Omacini et al. 2001), concepts of endophyte-grass interactions at all biological organisational levels have ensued. This begs the critical question: how well do agronomic grass-endophyte interactions represent the grassendophyte interactions in general?

To address this question, Saikkonen et al. (2006) conducted a meta-analysis of endophyte-grass studies, both in agronomic and natural or wild systems, of the literature until 2005. Metaanalysis is a quantitative method for combining data from individual primary studies that might be presented in different forms (e.g., different experimental protocols). Meta-analysis uses a standardised metric of the direction and magnitude of the variable of interest, termed effect size. First, Saikkonen et al. (2006) statistically examined temporal trends in the literature by cumulative meta-analyses. In these analyses, individual studies were added to the analysis in chronological order, and the summary statistics were re-calculated at each step. In early years, results of studies of endophyte effects on plant competition were highly variable, and not significantly different from zero (Fig. 2a). In 1999, the effect size was significantly positive (indicating endophytes enhanced competitive abilities) mainly due to one study by Clay \& Holah (1999) that involved the Kentucky 31 cultivar. After that, effect size remained significant until 2004, and then non-significant thereafter. For plant performance, metaanalysis shows much wider variability and overall effect sizes were only significantly positive in early years (Fig. 2b). Early studies of endophyte effects on herbivores were widely variable, but the overall positive effect size soon became significant (Fig. 2c). However, similarly to studies on plant competition and performance, the magnitude of the effect size gradually decreased nearly to zero and remained significant only because of decreased variance (Fig. 2c).

Studies involving agronomic tall fescue and perennial ryegrass dominated these studies, comprising $82 \%$ of all titles and $56 \%$ of all the studies included in the meta-analysis through 2005. Furthermore, the magnitude of the effect size of these two species and their endophytes is relatively small and does not differ from average effect size, but becomes significant because of a low variance relative to other grass species (Saikkonen et al. 2006). Furthermore, the studies showing positive effects were conducted in high nutrient environments while those in low nutrient soils were much more variable and not significantly different from 
Figure 3 Mean effect size and 95\% confidence interval of endophytes on their host grasses in different soil nutrient environments. Infected grasses in high nutrient environments (or in soils with unknown nutrient levels) have significantly positive effect sizes while those in low nutrient soils are not different from zero.

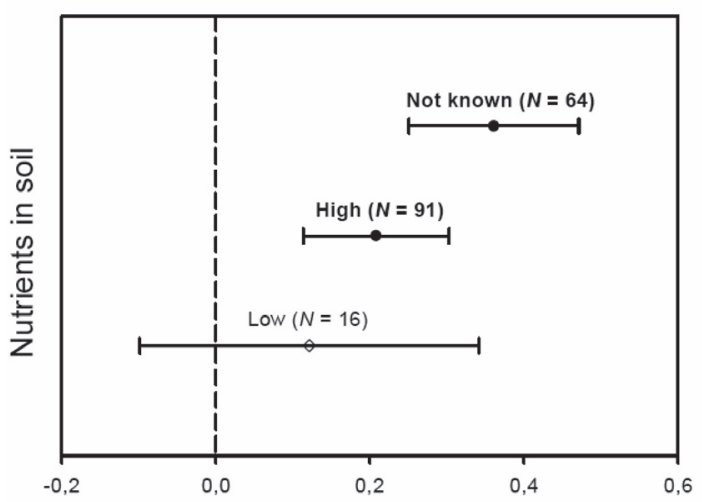

Effect size $(\mathrm{Zr}+95 \% \mathrm{Cl})$

zero (Fig. 3). Clearly then, high nutrient environments, such as those typically found in agroecosystems, can dramatically shift endophyte effects on their host grasses. These high nutrient environments are unlikely to be the norm in natural grass communities.

Tall fescue, especially the cultivar Kentucky 31, has been used extensively as a model system for testing the ecological effects and developing ecological and evolutionary concepts of endophyte-grass interactions (Saikkonen 2000). However, meta-analysis reveals that relative to other tall fescue cultivars and native tall fescue, variation is greatly reduced (Fig. 4). Moreover, the direction and magnitude of the effect size is significantly positive, while that for other cultivars and wild type tall fescues is not significant (Fig. 4). Kentucky 31 (K-31) has been experimentally used to demonstrate endophyte effects on population, community and ecosystem properties such as plant competition (Clay \& Holah 1999), herbivore resistance (e.g. Clay et al. 1993; Clay 2001), plant diversity (Clay \& Holah 1999), arthropod diversity (Finkes et al. 2006), allelopathy (Matthews \& Clay 2001), changes in endophyte frequencies (Clay et al. 2005), decomposition (Lemons et al. 2005; Mayer et al. 2005), soil properties (Matthews \& Clay 2001), effects on the third trophic level (e.g. Bultman \& Ganey 1995), and community invasiveness (Rudgers et al. 2004). However, it appears that K-31 tall fescue may poorly represent the variation found in natural systems.

The biological reasons that K-31 may not serve as a good model system are three-fold. First, K-31 tall fescue is a recently released cultivar from a few plants of an ecotype of an introduced tall fescue from Europe that was found growing on a hillside near Frenchburg, Kentucky in Menefee County in the 1930s (Buckner \& Bush 1979). This particular ecotype was selected because it survived long drought periods and intensive grazing, and thus appeared ideal for pastures degraded by the droughts, soil erosion and overgrazing of the Dust Bowl era in North America. The University of Kentucky released K-31 in 1943 and farmers rapidly increased acreage throughout the eastern US as well as that of a related variety, Alta in the Pacific Northwest. The seeds used in the aforementioned ecological studies were
Figure 4 Mean effect size and 95\% confidence interval of endophytes on their host grasses for different cultivars or wild tall fescue. Kentucky 31 shows significantly positive effect sizes with low variation relative to other cultivars and wild types of tall fescue, suggesting the Kentucky 31 system does not encompass wide variation in effects found in other infected tall fescue grasses.

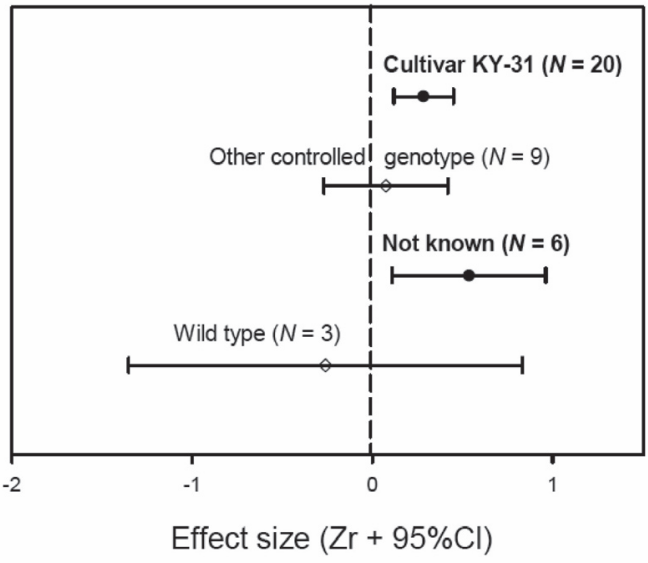

from stocks re-collected in 1988, and thus are < three generations removed from the original introduced grass from the hillside near Frenchburg (T. Phillips, personal communication). Thus, despite implications that K-31 is 'naturalised' and present since the 1800s in the US, seeds used in ecological experiments come from a very recently released and highly-selected cultivar. Furthermore, as an ecotype, seeds collected from the hillside farm were not outcrossed as are many agronomic cultivars to increase genetic variation to preserve the original ecotype traits (T. Phillips, personal communication). It is unclear how much plant genotypic variation K-31 harbours, but it appears similar to other outcrossing tall fescue cultivars. It is also uncertain exactly how or where K-31 originated in terms of countries in Europe or Asia, but both the endophyte ( $N$. coenophialum) and host grass are of northern European origin (T. Phillips \& C. Schardl, pers. communication). Nonetheless, there was likely a strong genetic bottleneck in host grass genotype at the time of introduction, as is the case for most introduced species, and at the time of selection of seed by agronomists at the University of Kentucky. Therefore, $\mathrm{K}-31$ is likely to show reduced genetic variation in terms of the host grass genetic background relative to wild populations.

Secondly, K-31 tall fescue harbours only one genetic variety of Neotyphodium endophyte. However, natural populations of tall fescue in endemic habitats harbour multiple haplotypes of Neotyphodium. Grass and endophyte genotype dramatically alter the properties and purported benefits attributed to endophyte infection. For example, Piano et al. (2006) recently found two distinct Neotyphodium endophytes in native tall fescue in Sardinia, and these differ radically in the average levels of alkaloids produced (Fig. 5). In other native grasses, including endemic populations of perennial ryegrass (Bony et al. 2001), properties such as alkaloid types and levels, physiological traits, and competitive abilities are dramatically altered by host or endophyte genotype (Faeth \& Sullivan 2003; Faeth et al. 2002, 2006; Morse et al. 2002; Morse \& Faeth 2006), such that variation within a given endophyte-host grass species is equivalent to that among infected grass species (e.g. Faeth et al. 2006).

Third, the majority of studies of agronomic grass cultivars, 
Figure 5 Variation in loline and ergovaline alkaloid levels from 58 native tall fescue populations in Sardinia, Italy (Piano et al. 2006). Populations were distinguished by two morphological forms of the Neotyphodium endophyte, a short- $(N=50)$ and a long-conidia $(N=8)$ form. Tall fescue with the more common short-conidia form produced far lower amounts of both loline and ergovaline alkaloids relative to the other form and to three agronomic cultivars of tall fescue. Within each form of Neotyphodium, considerable variation in alkaloid levels also exists, as evidenced by the standard error bars. Ergovaline levels were incorrectly reported in Piano et al. (2006, Table 3) as $\mu \mathrm{g} \mathrm{g}^{-1}$ instead of $\mu \mathrm{g} \mathrm{kg}^{-1}$ (F. Bertoli, pers. comm.); corrected data are shown here. Data courtesy of Federico Bertoli.

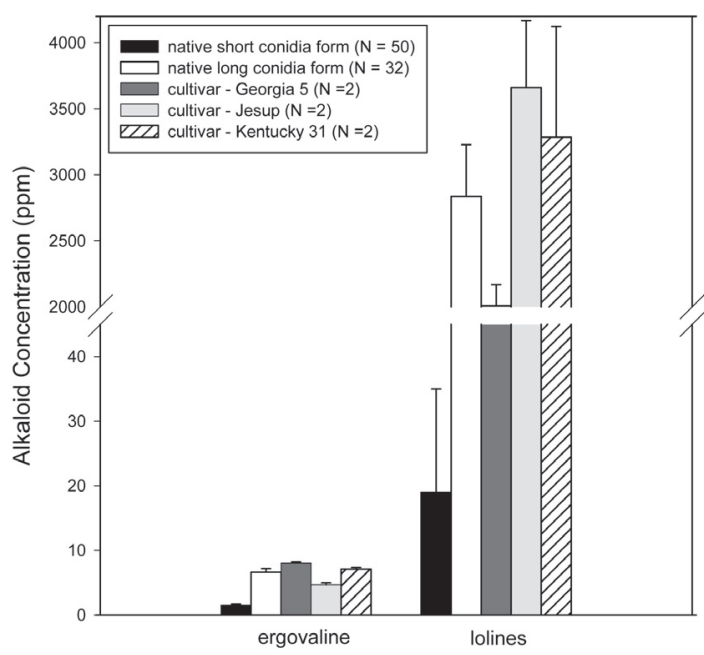

Alkaloids - Sardinia Native Populations and Tall Fescue Cultivars

including K-31 tall fescue and their endophytes occur in agroecosystems or former agroecosystems (e.g. old fields) where nutrient levels are typically high. As noted above, higher nutrient levels clearly alter outcomes of endophyte-grass interactions (Fig. 3 ), shifting effect sizes towards significantly positive directions.

Natural populations and communities are mosaics of uninfected and infected grasses of multiple endophyte and host genotypic combinations embedded in complex communities that are usually limited in availability of soil nutrients (Faeth \& Fagan 2002; Faeth 2002; Saikkonen 2000; Saikkonen et al. 2004, 2006). It thus seems highly unlikely that K-31 or any other agronomic cultivar, with a single endophyte type, limited host genetic variation and nutrient-enriched environments, can adequately serve as a model system to derive ecological and evolutionary concepts and principles of endophyte-grass interactions.

In the following sections, we provide recent examples of the enormous variation in endophyte-grass interactions in terms of physiology, host-herbivore interactions, trophic interactions, and community diversity and structure.

\section{Variation in Endophyte-Grass Interactions}

Variation in physiological and growth responses

Endophytes are well-known for altering host physiology and increasing resistance to abiotic stresses such as drought and low nutrients (e.g., Malinowski et al. 2005). The variation in host
Figure 6 Mean abundance of herbivores, natural enemies (predators and parasites), detrivores and all arthropods combined from infected Achnatherum robustum (sleepygrass) from infected plants with zero, low and high levels of alkaloids. Difference letters about bars indicate significant differences in means with in a feeding guild type $(\mathrm{P}<0.05$, Bonferroni correction for multiple comparisons).

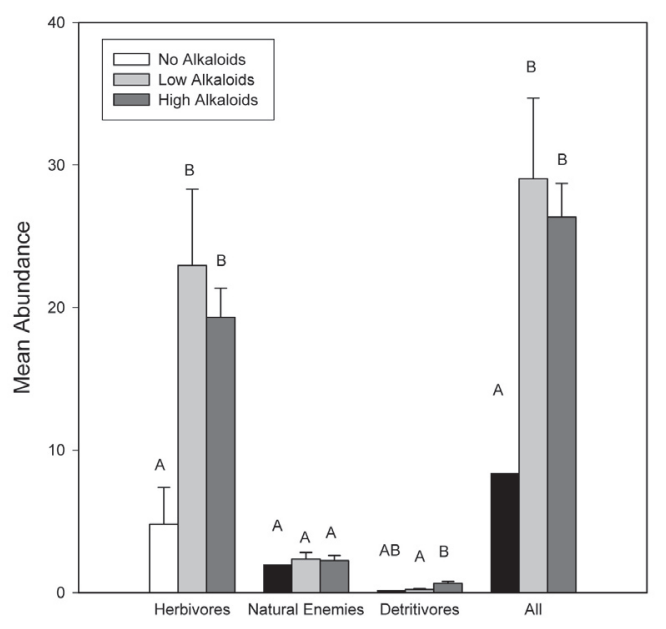

grass responses are highly dependent on host plant genotype and environmental factors (e.g. Ahlholm et al. 2002; Lehtonen et al. 2005a), and often host genotype and environment interact significantly to affect these physiological and growth responses (e.g. Cheplick et al. 2000). Plant genotype often exerts significant effects on plant physiology, growth rates, nutrient uptake, and competitive abilities even in tall fescue (e.g. Belesky et al. 1987; Marks \& Clay 1996) and perennial ryegrass (e.g. Hesse et al. 2004) cultivars where genetic variation is usually lower than wild grasses. Moreover, endophyte effects on host physiology and growth usually involve complex genotype $\mathrm{x}$ environment interactions (e.g. Cheplick et al. 2000; Hesse et al. 2004).

However, plant genotype constitutes only one half of the endophyte-grass genetic combination (Saikkonen et al. 2004). Agronomic cultivars of tall fescue and perennial ryegrass used in ecological experiments harbour one or very few endophyte haplotypes and thus omit a large contributor to genetic variation found in natural populations, which usually consist of multiple endophyte haplotypes embedded in a complex suite of host genetic backgrounds. More recent inoculations of novel endophytes into agronomic tall fescue hosts indicate that endophyte haplotype has profound effects on physiology and growth. For example, Hill et al. (1996) showed that different endophytes introduced into tall fescue hosts altered growth, leaf water potential, and turgor pressure in their hosts. Likewise, Assuero et al. (2000) found that the different endophyte strain AR501 in KY-31 altered growth rate, tiller number and photosynthetic rates. However, there is dearth of studies examining how endophyte haplotype and host genotypic combinations alter physiology and growth in natural populations.

The only study of which we are aware is that by Morse et al. (2007). They examined the physiology, morphology and growth of two distinct endophyte haplotypes (H1 and $\mathrm{H} 2$ ) found within different plant genotypes of Arizona fescue (Festuca arizonica), a native grass that is common in semi- 
Figure 7 Schematic and simple diagram showing the complex interactions in natural communities that harbouring multiple endophyte haplotypes within different plant genotypes.

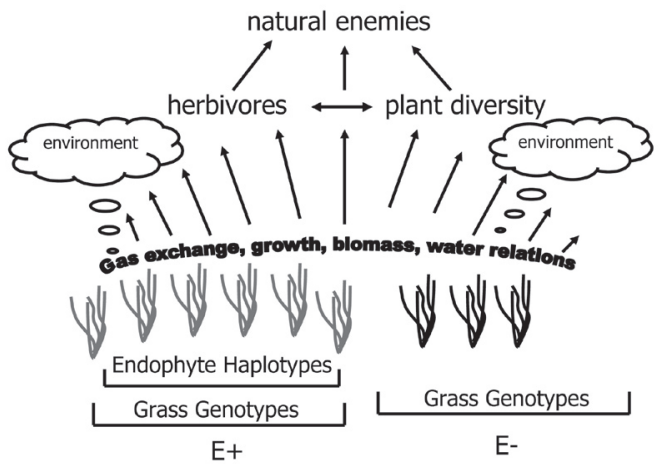

arid regions of the Southwestern USA. Infection was removed hydroponically from some clones of naturally infected maternal plants. Experiments were conducted in a growth chamber over 49 days and under different soil moisture regimes, and traditional growth parameters were measured. They also measured leaf net photosynthesis and dark respiration, leaf conductance to water vapour, leaf water potential, leaf rolling, and stomatal density to provide explanations for differences in biomass production and relative growth rates. Total biomass, below-ground and above ground biomass and most physiological measurements (except LAR, leaf area ratio) did not differ between E+ and E- plants. However, endophyte haplotype nested within plant maternal genotypes significantly affected total biomass, below-ground biomass and the ratio of below-ground to above-ground biomass. Furthermore, endophyte haplotype also altered the physiological parameters, including midday net photosynthesis $\left(P_{n}\right)$, leaf conductance to water vapour $\left(g_{s}\right)$, intercellular $\mathrm{CO}_{2}$ concentration $\left(c_{\mathrm{i}}\right)$, dark respiration, leaf water potential $\left(\Psi_{\mathrm{L}}^{2}\right)$. Host grass morphological features also differed between the two endophyte haplotypes, including leaf rolling and stomatal density. Morse et al. (2007) found complex and significant interactions between infection, endophyte haplotypes within plant genotypes and water treatments. Indeed, endophyte haplotype overshadowed variation attributable to endophyte status ( $\mathrm{E}+$ or $\mathrm{E}-$ ), which is usually the only endophyte-related variation examined in endophyte physiology and growth studies. These results argue strongly that variation in endophyte-host interactions in natural populations are likely to be highly complex and variable depending on endophyte and host genotype and prevailing environmental conditions. Because most native populations are composed of multiple endophyte haplotypes, some of hybrid origin, nestled within many different plant genotypes, we should expect outcomes in terms of plant physiology, morphology and performance that far exceed the variability in agronomic grass model systems.

\section{Variation in host grass herbivore interactions}

Historically, resistance to herbivores has been the first and major impetus for concluding that systemic endophytes are mutualistic symbionts of grasses. In 1876, Hance reported consumption of a grass in Mongolia caused intoxication in cattle. Toxicity in this grass, commonly called drunken horse grass, is now known to be caused by the recently described Neotyphodium ganuense ( $\mathrm{Li}$ et al. 2004). The causative agent of toxicoses in agronomic cool
Figure 8 Mean dry mass of herbivores on $\mathrm{E}+$ and $\mathrm{E}$ (endophyte removed) Arizona fescue plants.

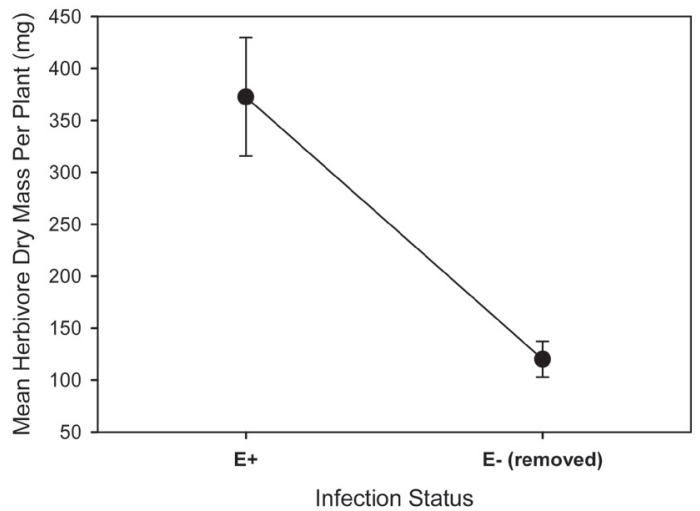

season grasses was first directly linked to systemic endophytes and their alkaloids in the 1970s. Bacon et al. (1977) determined that fescue toxicosis in cattle consuming K-31 tall fescue resulted from alkaloids produced by Neotyphodium coenophalium. Soon thereafter, systemic endophytes in grasses, particularly asexual Neotyphodium were proclaimed as 'acquired plant defenses' or 'defensive mutualists' (Cheplick \& Clay 1988; Clay 1988) and still are regarded largely as such today (e.g. Clay \& Schardl 2002; Schardl et al. 2004).

However the universality of herbivore resistance via alkaloids has been more recently called into question (e.g. Faeth 2002). While undoubtedly herbivore and pathogen resistance is a common outcome in agronomic grasses (Fig. 2c), studies of herbivore resistance in infected wild grasses produce much more variable outcomes (Lewis \& Clement 1986; Saikkonen et al. 1998, 1999, 2006; Tibbets \& Faeth 1999; Vinton et al. 2001; Faeth 2002; Müller \& Kraus 2005; Tintjer \& Rudgers 2006; Mirlohi et al. 2006). Likewise, endophyte-pathogen interactions are also variable. Infected native grasses may be more (e.g. Wäli et al. 2006) or less susceptible (e.g. Lehtonen et al. 2006) to grass pathogenic moulds and viruses, with complex interactions between pathogen strain and endophyte-host combinations. At least part of this variability can be attributed to the much wider variability in alkaloid types and levels found in natural populations relative to agronomic grasses (e.g. Fig. 5). The same appears true for wild populations of perennial ryegrass where variation in alkaloid levels is much greater than agronomic perennial ryegrass. Bony et al. (2001) surveyed 83 wild European populations of perennial ryegrass and found that different morphological strains of Neotyphodium lolii exhibited remarkable variation in levels of lolitrem B, ergovaline and peramine. Thus, we should expect far greater variation in natural communities which typically harbour different endophyte strains within diverse plant genotypic backgrounds.

Variation in endophyte-associated herbivore resistance increases when other trophic levels are considered

However, alkaloids are only part of the story of variation in herbivore resistance. Endophyte infection alters complex biochemical pathways other than simply those for alkaloid production, and thus results in multiple and complex effects on host grass biochemical and nutritional properties, at least in agronomic varieties of grasses (Newman et al. 2006). Most studies of herbivore resistance have involved $\mathrm{E}+$ and $\mathrm{E}$ - agronomic 
grasses, often in laboratory or greenhouse feeding experiments with no natural enemies and no complex community interactions. When other trophic levels are considered, the purported positive correlation between alkaloid levels and herbivore resistance (e.g. Clay \& Schardl 2002) may disappear or even become negative.

Alkaloids not only influence herbivores but also either directly or indirectly their natural enemies, just like constitutive (e.g. Barbosa et al. 1991) or induced (e.g. Faeth 1994) plant-based allelochemicals that alter efficacy of natural enemies. Any direct or indirect mechanism that reduces location and attack rate and survival and performance of natural enemies of herbivores may potentially nullify endophyte benefits to the host via increased deterrence and toxicity to herbivores. Alkaloids may directly increase resistance of herbivores to predators and parasites as they move through the food web and are sequestered by the herbivores and then used as part of their own defensive repertoire (Faeth \& Bultman 2002; Sassi et al. 2006; Chaneton \& Omacini 2006). Sequestration of alkaloids by herbivores would shortcircuit the purported defensive mutualism and endophytes and grasses. Sequestration of plants allelochemicals by specialist insect herbivores is well-known in the plant-herbivore literature (e.g. Bowers 1990). Specialists often evolve not only to detoxify plant toxins but to require them in their diets and sequester them as defenses against natural enemies. For example, Bultman et al. (1997) found that armyworms fed artificial diets with loline alkaloids, reduced growth and survival of two Euplectrus parasitoids of the fall armyworm feeding on E+ tall fescue. Likewise, they found that Aphenilus asychis parasitoids of $R$. padi aphids had lower mass when aphids were reared on $\mathrm{E}+$ tall fescue relative to E- tall fescue. In later experiments, Bultman et al. (2003) showed that the survival and development time of the parasitoid, Micronotus hyperodae decreased and slowed, respectively, when its host, the Argentine stem weevil, was fed on two cultivar varieties of infected perennial ryegrass. Omacini et al. (2001) in a field experiment with agronomic Italian ryegrass showed similar results. Infection in Italian ryegrass reduced the rate of parasitism by secondary parasitoids. Alkaloids may also be transmitted via food webs to generalist predators. Sassi et al. (2006) found that development time of generalist ladybird beetles (Coccinella septempunctata) increased while fecundity and survival decreased, when feeding on cereal aphids (R. padi) feeding on E+ perennial ryegrass.

All of the aforementioned studies involved agronomic grass cultivars, which in themselves demonstrate inherent variability in endophyte-herbivore interactions when natural enemies, the third trophic level are considered. Unfortunately, studies of endophytes, herbivores and natural enemies in natural communities are extremely scarce. The only one of which we are aware is Jani and Faeth (2006), who sampled the diversity and abundances of herbivores, predators and parasites, and detrivores from 87 infected grasses of Achnatherum robustum, sleepygrass, that varied in alkaloid levels from a natural community near Cloudcroft, NM, USA. Sleepygrass is a notoriously toxic grass, at least to livestock, with often extraordinarily high levels of ergot alkaloids but these alkaloid levels vary widely within and across populations (Faeth et al. 2006). Plants were grouped by alkaloids levels (no alkaloids, low alkaloids $(<68 \mathrm{ppm})$ and high alkaloids ( $>68$ ppm). Interestingly, Jani \& Faeth (2006) found significantly higher relative abundances of herbivores on low and high ergot alkaloid grasses relative to infected grasses without alkaloids (Fig. 6). Mean biomass of herbivores was also twofold greater on low $(115.7 \mathrm{mg})$ and high $(112.2 \mathrm{mg})$ alkaloid plants relative to no alkaloid $(58.2 \mathrm{mg})$, although not significantly so after alpha levels were adjusted for multiple comparisons. These results directly contradict conventional expectations that alkaloids reduce relative abundances of herbivores in agronomic grass systems (Table 1).

Neotyphodium infection and associated alkaloids have also been found to affect not only herbivore abundances but also herbivore species richness and the diversity of parasites and predators of the herbivores (Table 1). But again, these results have been from agronomic grass systems. In native sleepygrass, rarefaction analyses showed that total species richness did not differ between zero alkaloid and low and high alkaloid plants, but high alkaloid plants had significantly more herbivore species than low alkaloid plants (Jani \& Faeth 2006). When richness of natural enemies is examined, this pattern is reversed: high alkaloid plants had lower richness of natural enemies than low alkaloid plants (no alkaloid plants had too few natural enemies for meaningful comparisons). This difference was due to higher richness of predators on low alkaloid plants; parasitoid richness did not differ significantly between low and high alkaloid plants. Jani \& Faeth (2006) concluded that high alkaloid sleepygrass plants provide enemy-free space (sensu Jeffries \& Lawton 1984) for herbivores, and relative abundances of herbivores increase on these grass hosts. Clearly, additional studies of infected grasses are desperately needed before conclusions regarding the effects of endophytes on herbivore and natural enemy diversity can be made.

\section{More interacting species, more variation}

The picture gets even more complicated when other interacting species are involved. Entomopathogenic nematodes have their own symbiotic bacteria, which when injected into the host insect, multiply and serve as food for the offspring of the nematodes. Richmond et al. (2004) experimentally examined survival of fall armyworm larvae reared on E+ and E- perennial ryegrass, and expose to the nematode Steinernema carpocapsae or injected with just its symbiotic bacteria, Xenorhabdus nematophila. Larvae fed on E+ grass survived better than those fed E- in both instances. Thus, Richmond et al. (2004) concluded that alkaloids used by the herbivore effectively turn the tables on both plant and natural enemy'. Endophytes and their alkaloids also negatively affected the effectiveness of the same nematode on another host, the black cutworm (Agrotis ipsilon) by also interfering with the symbiotic bacteria of the nematode (Kunkel \& Grewal 2003; Kunkel et al. 2004). Once again, this interaction could thwart the defensive mutualisms of the endophytes with their host grasses, at least as related to defense against herbivores.

In natural communities, infected grass hosts do not exist in monocultures of other infected and uninfected grass hosts, but are typically surrounded by other interacting species. Lehtonen et al. (2005b) found that endophyte produced alkaloids can also be sequestered by hemiparasitic plants. In experimental studies of Lolium pratensis infected with Neoptyphodium uncinatum, they showed that a root hemiparasitic plant (Rhinanthus serotinus) acquires alkaloids from the host grass. The purloined alkaloids increase resistance of the hemiparasitic plant to the generalist aphid Aulacorthum solani. However, endophyte infection reduced the biomass of host grasses when parasitised by the hemiparasite. Thus, the mutualistic endophytic fungus becomes parasitic in the presence of another plant species, in this case a root hemiparasite. Had the grass-endophyte interaction been studied in isolation, very different conclusions about the outcomes of grass-endophyte interactions would have ensued. Other plantplant interactions, such as intra and interspecific competition, 
Figure 9 Mean seed mass from E+ and E- (endophyte removed) Arizona fescue plants under no herbivory (small mammals and invertebrate herbivores removed) and herbivory treatments.

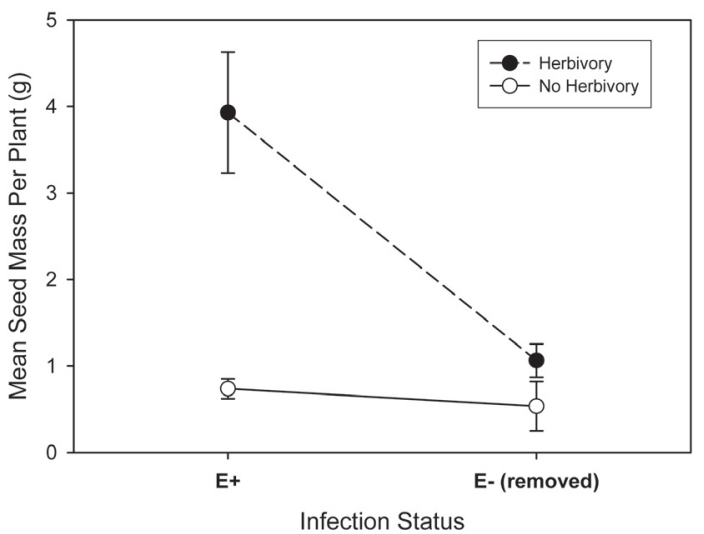

alter plant nutrition, growth and thus susceptibility to herbivores (Karban et al. 1989; Agrawal 2004). Plant competition also alters the ability to produce induced and constitutive chemical defenses (e.g. Karban \& Baldwin 1997; Cipollini 2004). Yet, to our knowledge, plant competition has not been rigorously tested as a factor influencing endophyte-associated alkaloids or induction of these alkaloids after herbivore damage (e.g. Bultman \& Ganey 1995). Surrounding plants also cause associational resistance, where neighbouring plants affect resistant traits of a focal plant (sensu Root 1973; Agrawal 2004). Thus, we should expect that in natural communities the surrounding matrix of interacting plant species will produce highly variable and perhaps unpredictable outcomes for endophyte-grass interactions.

Clearly, then endophytes and their alkaloids do not always act as defensive mutualists of plants and the interaction depends on alkaloid type and variation and other interacting species. So far, most of the studies to date have involved relatively simple laboratory assays of a single herbivore species with one or two natural enemy species, and fed $\mathrm{E}+$ and $\mathrm{E}$ - agronomic grasses, with limited genetic (and thus alkaloid) variability. The question has yet to be tested rigorously in natural communities, where multiple herbivore and natural enemy species, including microbial ones, form complex food webs on a mosaic of grass hosts that vary enormously in endophyte and host genotype and thus traits such as alkaloids types and levels. Omacini's et al. (2001) elegant study serves as caveat that considering even relatively simple food webs on for one strain of endophyte in a single grass cultivar produces enormously complex effects of infection for some species and trophic levels. In natural communities, the increased complexity of food webs, amplifies genotypic variation in the endophyte and host, and environmental fluctuations will magnify the possible outcomes of endophyte infection in grasses at the community level (Fig. 7).

\section{Neotyphodium in Native Grasses - Endophytes as Promoters} of Herbivory rather than Defensive Mutualists

The notion that Neotyphodium endophytes act as defensive mutualists is a deeply entrenched view based largely on the three agronomic grass models (e.g. Cheplick \& Clay 1988; Clay 1988; Clay \& Schardl 2002; Schardl et al. 2004). Yet, accumulating evidence from infected native grasses, some of these native versions of the agronomic grasses, indicates that Neotyphodium
Figure 10 The effects of herbivory on mean seed production of Arizona fescue plants $(E+$ and $E$ - plants combined).

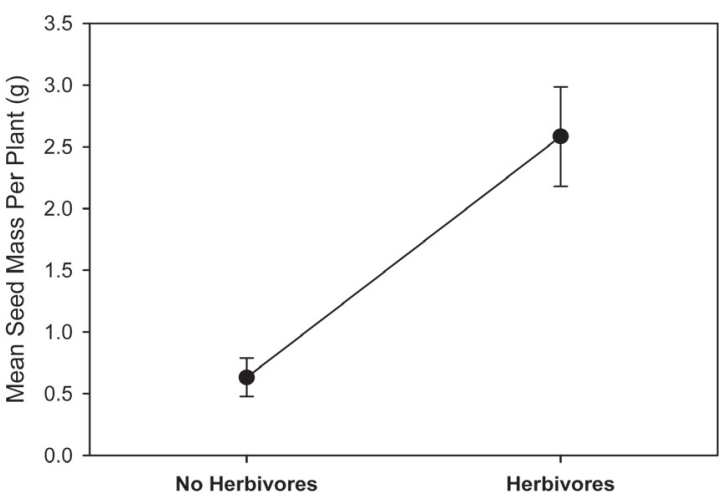

infection does not always deter herbivores (see refs. in Faeth 2002) and instead may not affect or even reduce resistance to herbivores and plant pathogens (e.g. Tibbets \& Faeth 1999; Clement et al. 2005; Wäli et al. 2006). While at first these empirical results seem counterintuitive, there is an ecological and evolutionary hypothesis that may explain this variability in herbivore resistance: Herbivory on vegetative parts of host grasses may increase seed production and thus propagation of Neotyphodium endophytes.

Seeds are the only purported mode of transmission for asexual Neotyphodium endophytes and a facultative mode for most Epichloë endophytes. If herbivory results in reallocation of host resources to reproduction, as may be the case for some plants (e.g. Anderson \& Paige 2003), then fitness of seed-borne endophytes may actually be enhanced by some types and levels of herbivory. If so, then we might expect endophytes to 'encourage' herbivory through reduced defenses or by increasing palatability or attractiveness of plant vegetative tissues. The same may hold for endophytes transmitted in ramets (e.g. Pan \& Clay 2003) because herbivory typically increases tillering (e.g. Pavlu et al. 2006), and thus propagation of infected clones.

To test this hypothesis, one of us (SHF) set up a long term field experiment with four different plant maternal genotypes of Arizona fescue (Festuca arizonica) infected with Neotyphodium. Clones of these plants were treated with fungicide to remove the endophyte from one half of the clones. Replicates of infected $(\mathrm{E}+)$ and uninfected (E-) clones of each plant genotype were grown outdoors in a common garden experiment with three water treatments (reduced, ambient, and supplemented water) and two herbivory treatments (ambient herbivory from arthropods and small mammals and no herbivory (via hardware cloth cages and periodic insecticide treatments). Plant growth (aboveground biomass) and reproduction (culms, flowers and seeds) were measured at the end of the growing season, as well as arthropod abundance and diversity (from the herbivory treatment plants, no- herbivory plants had no or very few insect herbivores).

E+ plants had significantly greater aboveground biomass than E- plants, indicating enhanced growth. Interestingly, E+ plants had significantly greater numbers and biomass of herbivorous insects (Fig. 8), despite levels of the alkaloid peramine in the four infected maternal plants averaging $11.05 \pm 0.40 \mathrm{ppm}$ (Eplants had no peramine). Clearly, peramine was not defensive 
Figure 11 Regression of Neotyphodium infection frequency in Arizona fescue (Festuca arizonica) and understorey plant species richness in high elevation, semiarid Ponderosa pine- grassland communities in Arizona. Plant species richness data from Rambo \& Faeth (1999). Infection frequency data partially from Faeth et al. (2002).

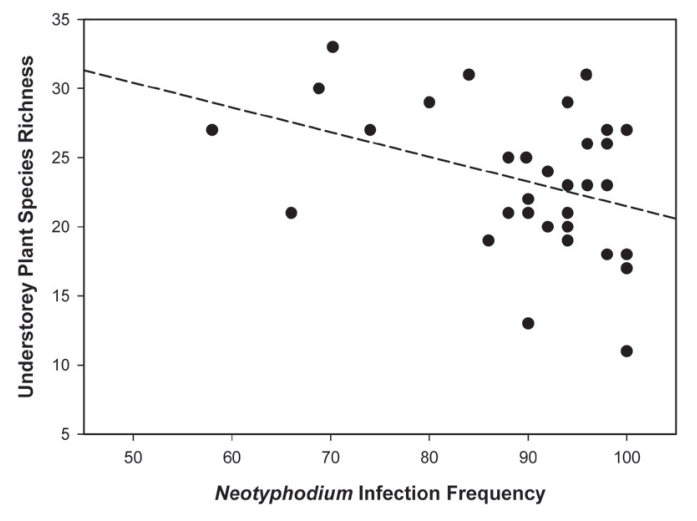

against insects in this case. The most intriguing result was that E+ plants had significantly higher mean average seed mass per plant but only in the treatment where herbivores were present (Fig. 9). In other words, herbivory and infection significantly interacted to affect seed production. When herbivores were excluded, seed mass did not differ between E+ and E- plants. E+ plants also had greater total reproductive mass (seeds, culms and inflorescences) and higher reproductive to vegetative mass ratios than E- plants - but again, only when herbivory was present. Furthermore, all experimental grasses (E+ and E-) subjected to herbivory produced five times more seed mass than those free of herbivory even though overall size of the plants was reduced by herbivory.

These results suggest that Neotyphodium endophytes in Arizona fescue plants benefit from increased herbivory in terms of plants producing more infected seeds. This could explain the puzzling results from previous studies showing that infected Arizona fescue is consistently less resistant to invertebrate (Lopez et al. 1995; Tibbets \& Faeth 1999) and vertebrate (Saikkonen et al. 1999) herbivory than their uninfected counterparts. It is as yet unclear how Neotyphodium in Arizona fescue is increasing herbivory and thus seed production. However, E+ plants have higher water content (Lopez et al. 1995) and altered physiological properties (Morse et al. 2002; Morse \& Faeth 2006), which may render infected plants more susceptible to sucking insects in semi-arid environments in Arizona. Whatever the mechanism, it appears that in the case of Arizona fescue and perhaps in other native grasses, infection by Neotyphodium promotes herbivory, which in turn, enhances production of seeds that house fungal hyphae.

Therefore, the oft-cited and ingrained concept that endophytes serve as defensive mutualists, derived from studies of infected agronomic grasses, may need to be reconsidered for some native grasses. Also, facilitation of herbivory means that endophytes may partially control plant growth and reproduction indirectly via herbivores. Thus, the long-held view, based upon agronomic grass models, is that asexual endophytes are 'trapped pathogens' or mutualistic 'slaves' (Wilkinson \& Schardl 1997; White et al. 2001) to the host and have no control on host-endophyte interactions may be erroneous. Instead, endophyte-host interactions are likely to be similar to other species interactions that vary temporally and geographically in strength and direction depending on genetics and environments (e.g. Saikkonen et al. 2004; Thompson 2005), and where each partner may exploit the other if it increases their respective fitness (e.g. Pellmyr et al. 1996).

\section{Variation in Community and Ecosystem Level Effects of Endophytes}

As the maternally-inherited component of infected grasses, endophytes may have profound effects on community patterns and processes, despite their miniscule biomass relative to other species in biological communities. For example, Clay \& Holah (1999) using Kentucky 31 tall fescue, found species richness declined in $\mathrm{E}+$ relative to $\mathrm{E}$ - plots, and $\mathrm{E}+$ dominance increased at the expense of other species, especially other grasses. In contrast to these findings, Spyreas et al. (2001) found a positive relationship between frequency of endophyte infection and plant diversity in a 3-yr-old successional field in Illinois. In later study, Clay et al. (2005) showed that endophyte frequency in Kentucky 31 tall fescue increased $30 \%$ over a $4.5 \mathrm{yr}$ period when insect and small mammalian herbivores were present. This shift in endophyte frequency in agronomic tall fescue is well known in pastures under heavy grazing pressure from livestock (Clay 1998). Species composition of the plant communities also differed between the herbivore and herbivore-exclusion plots although biomass remained the same. However, Tracy \& Renne (2005) found that the percentage of $\mathrm{E}+$ tall fescue did not increase relative to E- tall fescue over a 3 yr study of pastures with several plant species combinations, even though pastures were subjected to moderate grazing pressure from livestock.

Table 1 The effect of infection and alkaloids on herbivore and natural enemy abundances and species richness.

\begin{tabular}{|c|c|c|c|c|c|}
\hline Study system & $\begin{array}{l}\text { Herbivore } \\
\text { abundance }\end{array}$ & $\begin{array}{l}\text { Herbivore } \\
\text { richness }\end{array}$ & $\begin{array}{l}\text { Parasite } \\
\text { richness }\end{array}$ & $\begin{array}{l}\text { Predator } \\
\text { richness }\end{array}$ & References \\
\hline $\begin{array}{l}\text { Tall fescue K-31 } \\
\text { cultivar (introduced) }\end{array}$ & Decreased & Decreased & - & Decreased & 1,2 \\
\hline $\begin{array}{l}\text { Perennial ryegrass } \\
\text { cultivar (introduced) }\end{array}$ & Decreased & $\begin{array}{l}\text { Increased } \\
\text { coexistence }\end{array}$ & - & - & 3,4 \\
\hline $\begin{array}{l}\text { Italian ryegrass cultivar } \\
\text { (introduced) }\end{array}$ & Decreased & Unchanged & $\begin{array}{l}\text { Slightly } \\
\text { decreased }\end{array}$ & - & 5 \\
\hline Sleepygrass (native) & Increased & Increased & Unchanged & Decreased & 6 \\
\hline
\end{tabular}

${ }^{1}$ Clay 2001; ${ }^{2}$ Finkes et al. 2006; ${ }^{3}$ Härri \& Müller 2006; ${ }^{4}$ Meister et al. 2006; ${ }^{5}$ Omacini et al. 2001; ${ }^{6}$ Jani \& Faeth 2006 
We know virtually nothing about the effects of endophyte infection on plant diversity in natural communities. The studies of both Clay \& Holah (1999) and Spyreas et al. (2001) involved a single cultivar of tall fescue (K-31) harbouring a single Neotyphodium endophyte in successional old fields where introduced Eurasian weeds were a significant component of the plant community. The only study of endophyte infection and the relationship to plant diversity in natural communities of which we are aware involves Arizona fescue in semi-arid Ponderosa pine-grassland communities. In 1996, S.H. Faeth and J.L. Rambo surveyed 34 populations across high elevation communities for understorey plant diversity and Neotyphodium infection frequency. Plant species richness of forbs, grasses, shrub and trees was determined in ten $1 \mathrm{~m}^{2}$ quadrats at $10 \mathrm{~m}$ intervals along a randomly placed transect. Details of the plant species richness survey can be found in Rambo \& Faeth (1999). Infection frequency was determined by randomly sampling at least 50 Arizona fescue plants in each population near the transects. Plant species richness was negatively related $(\mathrm{F}=5.31, \mathrm{df}=1,33, \mathrm{P}=$ 0.03 ) to frequency of endophyte infection (Fig. 10). However, the regression explained only $14 \%$ of the variation, suggesting factors other than endophyte frequency may better explain variation in plant species richness. Also, there was no difference between grazed $(\mathrm{N}=5)$ and ungrazed $(\mathrm{N}=29)$ populations (by large vertebrates grazers) in terms of the relationship between plant species diversity and endophyte frequency, although grazed populations had higher plant species richness (Rambo \& Faeth 1999). Clearly, other studies of the relationship between endophyte infection frequency and plant species richness are needed, especially in natural plant communities, before any firm conclusions can be drawn.

\section{Community and ecosystem effects - decomposition and nutrient cycling}

Although endophytes in grasses inhabit the aboveground tissues, they have the potential to influence belowground ecosystem processes, such as rates of decomposition and nutrient cycling (Bernard et al. 1997; Franzluebbers et al.1999; Matthews \& Clay 2001; Omacini et al. 2004; Mayer et al. 2005). In terms of nutrient cycling, endophytes may increase phosphorous and nitrogen uptake in nutrient poor soils (e.g. Malinowski et al. 2005). Alternatively, fungal endophytes, at least in agronomic grasses, may inhibit mycorrhizae (Guo et al. 1992; Chu-Chou et al. 1992; Bernard et al. 1997; Omacini et al. 2006) and thereby reduce nutrient uptake. Also, E+ agronomic tall fescue indirectly alters soil properties which in turn alter success of other plant species (Matthews \& Clay 2001), either through allelopathic mechanisms, altered soil pathogens or alteration in available resources.

In terms of decomposition, infection at least in agronomic E+ grasses, often retards decomposition rates. Omacini et al (2004) demonstrated with litter bag experiments that E+ Lolium multiflorum decomposed slower than a co-occurring and uninfected grass, Bromus unioloides, under a range of soil moisture conditions. Furthermore, E+ Italian ryegrass changed the decomposition environment such that Bromus decomposed more slowly under a mat of E+ ryegrass compared to E- ryegrass. Similarly, Lemons et al. (2005) found that decomposition was slower in E+ agronomic tall fescue plots relative to E- plots in an experimental Indiana old field. The composition of the soil invertebrate community shifted, especially in the Collembola (springtail communities). However, again there is variability in outcomes, even in agronomic tall fescue infected with a single endophyte haplotype. For example, Mayer et al. (2005) found that decomposition rates of old fields in Oklahoma were significantly and positively related to the relative proportion of infected tall fescue. They concluded that macroinvertebrate decomposers were attracted to the better litter quality of tall fescue, $\mathrm{C}_{3}$, relative to other forbs and $\mathrm{C}_{4}$ grasses in the old field, despite infected tall fescue's toxicity. It seems, therefore, that the relative decomposition rates and effects on soil invertebrate communities may depend on local plant species composition and soil environments. These factors are certainly much more complex and variable in natural communities.

We are unaware of any studies of decomposition rates of infected native grasses in natural communities. However, given the conflicting results even from agronomic tall fescue studies, it would not be surprising that the effects of endophytes in natural communities on nutrient cycling and decomposition rates are multifarious and context dependent (e.g. Fig. 7). Certainly, such studies are needed in natural communities before any broad conclusions of the effects of endophytes on decomposition and nutrient cycling can be made.

\section{Conclusions}

So far, the vast majority of Neotyphodium studies have occurred in agroecosystems using two agronomic grasses, tall fescue and perennial ryegrass, and more recently a third agronomic grass, annual Italian ryegrass (Fig. 1). Whereas these systems can provide important insights into management of agronomic turf and pasture grasses, livestock and pest herbivores, these systems fail to capture the enormous variability in wild grasses at the physiological, population, community and ecosystem levels. Agroecosystems may provide some basic insights into ecological and evolutionary processes, as they have for theories of food webs (e.g. Mills \& Getz 1996). However, it is critical to recognise the limitations, and even past misdirections, of these systems in terms of the development of the concepts of the ecology and evolution of endophyte-grass interactions. Just as ecologists and evolutionary biologists would be very reluctant to form ecological and evolutionary theory and concepts based only upon cultivated food crop plants such as corn, rice or wheat, the same should hold for agronomic grasses, which are essentially crop plants cultivated for turf and pasture production. Our goal is not to admonish but instead urge caution in extrapolating agro-ecosystems to natural populations and communities and to call for increased studies of the latter systems. This is not a new warning - several earlier reviews and studies have done so but have been largely ignored (Saikkonen et al. 1998, 2004, 2006; Faeth 2002; Faeth and Sullivan 2003; Faeth et al. 2004). We believe it is time to shift the research emphasis, at least in terms of developing ecological and evolutionary concepts of endophytegrass interactions, from agronomic grass model systems that fail to encompass natural variation and complexity to endophytes inhabiting natural grass populations and communities where this complexity (e.g. Fig. 7) drives the ecology and evolution of endophyte-host interactions.

\section{REFERENCES}

Agrawal, A.A. 2004. Resistance and susceptibility of milkweed: competition, root herbivory, and plant genetic variation. Ecology 85:2118-2133.

Ahlholm, J.U.; Helander M.; Lehtimäki S.; Wäli P.; Saikkonen K. 2002. Vertically transmitted endophytes: effects of environmental conditions. Oikos 99: 173-183.

Anderson, L.L.; Paige K.N. 2003. Multiple herbivores and 
coevolutionary interactions in an Ipomopsis hybrid swarm. Evolutionary Ecology 17:139-156.

Assuero, S.G.; Matthew, C.; Kemp, P.D.; Latch, G.C.M.; Barker, D.J.; Haslett, S.J. 2000. Morphological and physiological effects of water deficit and endophyte infection on contrasting tall fescue cultivars. New Zealand Journal of Agricultural Research 43: 49-61.

Bacon, C.W.; Porter, J.K.; Robbins, J.D.; Luttrell, E.S. 1977. Epichloë typhina from toxic tall fescue grasses. Applied Environmental Microbiology 34: 576-581.

Barbosa P.; Gross, P.; Kemper, J. 1991. Influence of plant allelochemicals on the tobacco hornworm and its parasitoid, Cotesia congregata. Ecology 72:1567-1575.

Belesky, D.P.; Devine O.J.; Pallas, J.E. Jr.; Stringer, W.C. 1987. Photosynthetic activity of tall fescue as influenced by fungal endophyte. Photosynthetica 21:82-87.

Bernard, E.C.; Gwinn, K.D.; Pless C.D.; Williver, C.D.1997. Soil invertebrate species diversity and abundance in endophyte infected tall fescue, pp. 125-136. In Neotyphodium/Grass interactions. Eds. Bacon, C.W., Hill, N.S. Plenum Press, New York.

Bony, S.; Pichon N.; Ravel, C.; Durix, A; Balfourier, C.; Guillaumin, J-J. 2001. The

relationship between myotoxin synthesis in fungal endophytes of Lolium perenne. New

Phytologist 152:125-137.

Bowers, M.D. 1990. Recycling plant natural products for insect defense. pp. 353-386. In: Insect Defenses. Eds. Evans, D.L.; Schmidt, J.O., State University of New York Press, Albany, NY.

Breen, J.P. 1994. Acremonium endophyte interactions with enhanced plant resistance to insects. Annual Review of Entomology 39: 401-423.

Buckner, R.C.; Bush, L.P. 1979. Tall fescue. Soil Science of America, Inc. Madison, WI. USA.

Bultman, T.L.; Ganey, D.T. 1995. Induced resistance to fall armyworm (Lepidoptera: Noctuidae) mediated by a fungal endophyte. Environmental Entomology 24:1196-1200.

Bultman T.L.; Borowicz, K.L.; Schneble, R.M.; Coudron, T.A.; Crowder, R.J.; Bush, L.P. 1997. Effect of a fungal endophyte and loline alkaloids on the growth and survival of two Euplectrus parasitoids. Oikos 78: 170-176.

Bultman T.L.; McNeill, M.R.; Goldson, S.L. 2003. Isolatedependent impacts of fungal endophytes in a multitrophic interaction. Oikos 102: 491-496.

Chaneton, E.J., Omacini, M. 2006. Bottom-up cascades induced by fungal endophytes in multitrophic systems. In: Ecological Communities: Plant Mediation in Indirect Interactions webs. Eds. Ohgushi, T.; Craig, T.P.; Price, P.W., Cambridge University Press (in press).

Cheplick, G.P.; Clay, K. 1988. Acquired chemical defenses of grasses: The role of

fungal endophytes. Oikos 52: 309-318.

Cheplick, G.P.; Perera, A.; Koulouris, K. 2000. Effect of drought on the growth of Lolium perenne genotypes with and without fungal endophytes. Functional Ecology 14:657-667.

Chu-Chou, M.; Guo, G.; An, Z.Q.; Hendrix, J.W.; Serriss, R.S.; Siegel, M.R.; Dougherty, C.T.; Burrus, P.B. 1992. Suppression of mycorrhizal fungi in fescue by the Acremonium coenophialum endophyte. Soil Biology and Biochemistry 24: 633-637.

Cippolini, D. 2004. Stretching the limits of plasticity: can a plant defend against both competitors and herbivores? Ecology 85: 28-37.
Clay, K. 1998. Fungal endophyte infection and the population dynamics of grasses. pp. 255-285. In: Population Biology of Grasses. Ed. Cheplick, G.P. Cambridge University Press, Cambridge, UK.

Clay, K. 1988. Fungal endophytes of grasses: a defensive mutualism between plants and fungi. Ecology 69: 10-16.

Clay, K. 2001. Symbiosis and the regulation of communities. American Zoologist 41: 810-824.

Clay, K.; Marks, S.; Cheplick, G.P. 1993. Effects of insect herbivory and fungal endophyte infection on competitive interactions among grasses. Ecology 74: 1767-1777.

Clay, K.; Holah, J. 1999. Fungal endophyte symbiosis and plant diversity in successional fields. Science 285: 1742-1744.

Clay, K.; Schardl, C. 2002. Evolutionary origins and ecological consequences of endophyte symbiosis with grasses. American Naturalist 160: S99-S127.

Clay, K.; Hardy, T.N.; Hammond, A.M. Jr. 1985. Fungal endophytes of grasses and their effects on an insect herbivore. Oecologia 66:1-5.

Clay, K.; Holah, J.; Rudgers, J.A. 2005. Herbivores cause a rapid increase in hereditary symbiosis and alter plant community composition. Proceedings of the National Academy of Sciences 102: 12465-12470.

Clement, S.L.; Elberson, L.R.; Bosque-Pérez, N.A; Schotzko, D.J. 2005. Detrimental and neutral effects of wild barley - Neotyphodium fungal associations on insect survival.

Entomologia experimentalis et applicata 114: 119-125.

Faeth, S.H. 1994. Induced plant responses: effects on parasitoids and other natural enemies of phytophagous insects. pp. 245260. In: Parasitoid Community Ecology. Eds. Hawkins, B.A; Sheehan, W.S. Oxford University Press, Oxford, UK.

Faeth, S.H. 2002. Are endophytic fungi defensive plant mutualists? Oikos 98: 25-36.

Faeth, S.H.; Bultman, T.L. 2002. Endophytic fungi and interactions among host plants, herbivores and natural enemies. pp. 89-123. In: Multitrophic Level Interactions. Eds. Tscharntke, T.; Hawkins, B.A. Cambridge University Press, Cambridge, UK.

Faeth, S.H.; Bush, L.P.; Sullivan, T.J. 2002. Peramine alkaloid variation in Neotyphodium-infected Arizona fescue: effects of endophyte and host genotype and environments. Journal of Chemical Ecology 28: 1511-1525.

Faeth, S.H.; Fagan, W.F. 2002. Fungal endophytes: common host plant symbionts but uncommon mutualists. Integrative and Comparative Biology 42: 360-368.

Faeth, S.H.; Sullivan, T.J. 2003. Mutualistic asexual endophytes in a native grass are usually parasitic. American Naturalist 161:310-325.

Faeth, S.H.; Helander, M.L.; Saikkonen, K.T. 2004. Asexual Neotyphodium endophytes in a native grass reduce competitive abilities. Ecology Letters 7: 304-313.

Faeth, S.H.; Gardner, D.; Hayes, C.J.; Jani, A.; Wittlinger, S.K. 2006. Temporal and spatial variation in alkaloid levels in Achnatherum robustum, a native grass infected with the endophyte Neotyphodium. Journal of Chemical Ecology 32: 307-324

Finkes, L.K.; Cady, A.B.; Mulroy, J.C.; Clay, K.; Rudgers, J.A. 2006. Plant-fungus mutualism affects spider composition in successional fields. Ecology Letters 9: 344-353.

Franzluebbers, A.J.; Nazih, N.; Stuedemann, J.A.; Fuhrmann, J.J.; Schomberg, H.H.; Hartel, P.G. 1999. Soil carbon and nitrogen pools under low and high endophyte infected tall fescue. Soil Science Society of America Journal 63: 1687-1694. 
Goldson, S.L.; Proffitt, J.R.; Fletcher, L.R.; Baird, D.B. 2000. Multitrophic interaction

between the ryegrass Lolium perenne, its endophyte Neotyphodium lolii, the weevil pest

Listronotus bonariensis, and its parasitoid Microctonus hyperodae. New Zealand Journal

of Agricultural Research 43: 227-233.

Guo, B.; Hendrix, J.; An, Z.; Ferriss, R.S. 1992. Role of Acremonium endophyte of fescue on inhibition of colonization and reproduction of mycorrhizal fungi. Mycologia 84: 882-885.

Grewal, S.K.; Grewal, P.S.; Gaugler, R. 1995. Endophytes of fescue grasses enhance

susceptibility of Popillia japonica larvae to an entomophagous nematode. Entomologia

experimentalis et applicata 74: 219-224.

Hance, H.F. 1876. On a mongolian grass producing intoxication in cattle. Journal of Botany 14: 210-212.

Härri, S.A.; Müller, C.B. 2006. Grass endophytes mediate coexistence between aphid species. Ecological Society of America, 91 ${ }^{\text {st }}$ Annual Meeting, Memphis TN (abstract).

Hesse, U.; Hahn, H.; Andreeva, K.; Förster, K.; Warnstorff, K.; Schöberlein, W.; Diepenbrock, W. 2004. Investigations on the influence of Neotyphodium endophytes on plant growth and seed yield of Lolium perenne genotypes. Crop Science 44: 1689-1695.

Hill, N.S.; Pachon, J.G.; Bacon, C.W. 1996. Acremonium coenophialum mediated short- and long- term drought acclimation in tall fescue. Crop Science 36: 665-672.

Huitu, O.; Helander, M.; Lehtonen, P.; Saikkonen K. 2006. Fungi crying for help? Grass endophytes enhance the UV-visibility of vole urine in the eyes of their avian predators. International Botanical Congress, Vienna Austria (abstract).

Jani, A.J.; Faeth, S.H. 2006. Asexual fungal symbionts in native grasses: do they alter arthropod community structure? Ecological Society of America, $91^{\text {st }}$ Meeting, abstract .

Jeffries, M.J.; Lawton, J.H. 1994. Enemy free space and the structure of ecological communities. Biological Journal of the Linnean Society 23: 269-286.

Karban, R.; Brody,A.K.; Schnathorst, W.C. 1989. Crowding and a plant's ability to defend itself. American Naturalist 134: 749-760.

Karban, R.;Baldwin I.T. 1997. Induced Responses to Herbivory. University of Chicago Press, Chicago, IL, USA.

Kraus, J.; Härri, S.A.; Bush, L.; Husi, R.; Bigler, L.; Power, S.A.; Müller, C.B. 2006. Effects of fertiliser, fungal endophytes and plant cultivar on the performance of insect herbivores and their natural enemies. Functional Ecology: in press.

Kunkel, B.A.; Grewal, P.S. 2003. Endophyte infection in perennial ryegrass reduces

susceptibility of Agrotis ipsilon to an entomopathogenic nematode. Entomologia

experimentalis et applicata 107: 95-104.

Kunkel, B.A.; Grewal, P.S.; Quiley, M.F. 2004. A mechanism of acquired resistance against an entomopathogenic nematode by Agrotis ipsilon feeding on perennial ryegrass harboring a fungal endophyte. Biological Control 29:100-108.

Lehtonen, P.; Helander, M.; Saikkonen, K. 2005a. Are endophytemediated effects on herbivores conditional on soil nutrients? Oecologia 142: 38-45.

Lehtonen, P.; Helander, M.; Wink, M.; Sporer, F.; Saikkonen, K. 2005b. Transfer of endophyte-origin defensive alkaloids from a grass to a hemiparasitic plant. Ecology Letters 8:
$1256-1263$

Lehtonen, P.; Helander, M.; Siddiqui, S.A.; Lehto, K.; Saikkonen, K. 2006. Endophytic fungus decrease plant virus infections in meadow fescue (Lolium pratense). Biology Letters: in press.

Lemons, A.; Clay, K.; Rudgers, J.A. 2005. Connecting plantmicrobial interactions above and belowground: a fungal endophyte affects decomposition. Oecologia 145: 595-604

Lewis, G.C.; Clement, R.O. 1986. A survey of ryegrass endophyte in the U.K. and its apparent ineffectuality on a seedling pest. Journal Agricultural Sciences Cambridge 107: 633-638.

Li, C.J.; Nan, Z.B.; Paul, V.H.; Dapprich, P.D.; Liu, Y. 2004. Neotyphodium species symbiotic with drunken horse grass (Achnatherum inebrians) in China. Mycotaxon 90:141-147.

Lopez, J.E.; Faeth, S.H.; Miller, M. 1995. The effect of endophytic fungi on herbivory by red- legged grasshoppers (Orthoptera: Acrididae) on Arizona fescue. Environmental Entomology 24: $1576-1580$.

Malinowski, D.P.; Belesky, D.P.; Lewis, G.C. 2005. Abiotic stresses in endophytic grasses. Pp. 187-199. In: Neotyphodium in Cool-Season Grasses. Eds. Roberts, C.A.; West C.P.; Spiers, D.E. Blackwell Publications, Ames, Iowa.

Marks S.; Clay, K.1996. Physiological responses of Festuca arundinacea to fungal

endophyte infection. New Phytologist 133: 727-733.

Mayer, P.M.; Tunnell, S.J.; Engle, D.M.; Jorgensen, E.E.; Nunn, P. 2005. Invasive grass alters litter decomposition by influencing macrodetrivores. Ecosystems 8: 200-209.

Matthews, J.W.; Clay, K. 2001. Influence of fungal endophyte infection on plant-soil feedback and community interactions. Ecology 82: 500-509.

Meister, B; Krauss, J.; Härri, S.A; Schneider, M.V.; Müller, C.B. 2006. Fungal endosymbionts affect aphid population size by reduction of adult life span and fecundity. Basic and Applied Ecology 7:244-252.

Mirlohi, A.; Sabzalian, M.R.; Sharifnabi, B.; Nekoui, M.K. 2006. Widespread occurrence of Neotyphodium-like endophyte in populations of Bromus tomentellus Boiss. in Iran. FEMS Microbiology Letters 256: 126-131.

Mills, N.J.; Getz,W.M. 1996. Modelling the biological control of insect pests: A review of host-parasitoid models. Ecological Modelling 92: 121-143.

Morse, L.J.; Day, T.A.; Faeth, S.H. 2002. Effect of Neotyphodium endophyte infection on growth and leaf gas exchange of Arizona fescue under contrasting water availability regimes. Environmental and Experimental Botany 48:257-268.

Morse, L.J.; Faeth, S.H.; Day, T.A. 2007. Neotyphodium interactions with a native grass are driven mainly by the endophyte haplotype. Functional Ecology: in press.

Müller, C.B.; Krauss, J. 2005. Symbiosis between grasses and asexual fungal endophytes. Current Opinion in Plant Biology 8: 450-456.

Newman, J.A.; Rasmussen S.; Parsons, A.J.; Popay, A. 2006. A multidimensional quantitative approach to endophytic fungihost interactions: implications for herbivores. Ecological Society of America, $91^{\text {st }}$ Meeting, abstract.

Olff, H.; Ritchie, M.E. 1998. Effects of herbivores on grassland plant diversity.

Trends in Ecology \& Evolution 13: 261-265.

Omacini, M.; Chaneton, E.J.; Ghersa, C.M.; Müller, C.B. 2001. Symbiotic fungal

endophytes control insect host-parasite interaction webs. Nature 409: 78-81.

Omacini, M.; Chaneton, E.J.; Ghersa; Otero, P. 2004. Do foliar 
endophytes affect grass litter decomposition? A microcosm approach using Lolium multiflorum. Oikos 104: 581-590.

Omacini, M.; Eggers, T.; Bonkowski, M.; Gange, A.C.; Jones, T.H. 2006. Leaf endophytes affect mycorrhizal status and growth of co-infected and neighbouring plants. Functional Ecology 20: 226-232.

Pan, J.J.; Clay, K. 2003. Infection by the systemic fungus Epichloë glyeriae alters clonal growth of its grass host, Glyceria striata. Proceedings of the Royal Society of London B 270: 1585-1591.

Pavlu, V.; Hejcman, M.; Pavlu, L.; Gaisler, J.; HejcmanovaNezerkova, P.; Meneses. L. 2006. Changes in plant densities in a mesic species-rich grassland after imposing different grazing management treatments. Grass and Forage Science 61: 42-51.

Pellmyr, O.; LeebensMack, J.; Huth, C.J. 1996. Non-mutualistic yucca moths and their evolutionary consequences. Nature 380:155-156.

Piano, E.; Bertoli, F.B.; Romani, M.; Tava, A.; Riccioni, L.; Valvassori, M.; Carroni A.M.;

Pecetti, L. 2005. Specificity of host-endophyte association in tall fescue populations from

Sardinia, Italy. Crop Science 45:1456-1463.

Rambo, J.L.; Faeth, S.H. 1999. The effect of vertebrate grazing on plant and insect

community structure. Conservation Biology 13: 1047-1054.

Richmond, D.S.; Kunkel, B.A.; Somesekar, N.; Grewal, P.S. 2004. Top-down and bottom-up regulation of herbivores: Spodoptera frugiperda turns tables on endophyte-mediated plant defence and virulence of an entomopathogenic nematode. Ecological Entomology 29: 353-360.

Robert, J.S. 2004. Model systems in stem cell biology. BioEssays 26: 1005-1012.

Root, R.R. 1973. Organization of a plant-arthropod association in simple and diverse habitats: the fauna of collards (Brassica oleracea). Ecological Monographs 43:95-124.

Rowan, D.D.; Dymock, J.J; Brimble, M.A. 1990. Effect of fungal metabolite peramine and analogs on feeding and development of argentine stem weevil (Listronotus bonariensis). Journal of Chemical Ecology 16: 1683-1695.

Rudgers, J.A.; Koslow, J.M.; Clay, K. 2004. Endophytic fungi alter relationships between diversity and ecosystem properties. Ecology Letters 7: 42-51.

Saikkonen, K. 2000. Kentucky 31, far from home. Science 287: $1887 \mathrm{a}$

Saikkonen, K.; Faeth, S.H.; Helander, M.; Sullivan, T.J. 1998. Fungal endophytes: a

continuum of interactions with host plants. Annual Review of Ecology and Systematics 29: 319-343.

Saikkonen, K.; Helander, M.; Faeth, S.H.; Schulthess, F.; Wilson,
D. 1999. Endophyte-grass- herbivore interactions: the case of Neotyphodium endophytes in Arizona fescue populations. Oecologia 121: 411-420.

Saikkonen, K.; Wäli, P.; Helander, M.; Faeth, S.H.. 2004. Evolution of endophyte-plant symbioses. Trends in Plant Science 9:275-280.

Saikkonen, K.; Lehtonen, P.; Helander, M.; Koricheva, J.; Faeth, S.H. 2006. Model systems in ecology: dissecting the grassendophyte literature. Trends in Plant Science 11: 428-433.

Sassi, C.; Muller, C.B.; Krauss, J. 2006. Fungal plant endosymbionts alter life history and reproductive success of aphid predators. Proceedings of the Royal Society BBiological Sciences 273: 1301-1306.

Schardl, C.L.; Leuchtmann, A.; Spiering, M.J. 2004. Symbioses of grasses with seedborne fungal endophytes. Annual Reviews in Plant Biology 55: 315-340.

Spyreas, G.; Gibson, D.J.; Basinger, M. 2001. Endophyte infection levels of native and naturalized fescues in Illinois and England. Journal of the Torrey Botanical Society 128: 25-34.

Thompson, J.N. 2005. The geographic mosaic of coevolution. The University of Chicago Press, Chicago, IL.

Tibbets, T.M.; Faeth, S.H. 1999. Neotyphodium endophytes in grasses: deterrents or promoters of herbivory by leaf-cutting ants? Oecologia 118: 297-305.

Tintjer, T.; Rudgers, J.A. 2006. Grass-herbivore interactions altered by strains of a native endophyte. New Phytologist 170: 513-521.

Tracy, B.F.; Renne, I.J. 2005. Reinfestation of endophtye-infected tall fescue in renovated endophyte-free pastures under rotational stocking. Journal of Agronomy 97: 1473-1477.

Vinton, M.A.; Kathol, E.S.; Vogel, K.P., Hopkins, A.A. 2001. Endophytic fungi in Canada wild rye in natural grasslands. Journal of Range Management 54: 390-395.

White, J.F. Jr.; Sullivan, R.; Moy, M. 2001. An overview of the biology and systematics of Neotyphodium endophytes. pp.17$30 \mathrm{In}$ : Proceedings of the $4^{\text {th }}$ International Neotyphodium/ Grass Interactions Symposium. Eds. Dapprich, P.D.; Paul, V.H. Fachbereich Agrarwirtschaft, Soest, Germany.

Wilkinson, H.H.; Schardl, C.L. 1997. The evolution of mutualism in grass-endophyte associations. pp. 13-25 In: Neotyphodium/Grass Interactions. Eds. Bacon, C.W.; Hill, N.S. Plenum Press, New York, NY.

Wäli, P.R.; Helander, M.; Nissinen, O.; Saikkonen, K. 2006. Susceptibility of endophyte-infected grasses to winter pathogens (snow molds). Canadian Journal of Botany 84: 1043-1051. 